\title{
A POSTCOLONIAL READING OF RACIAL AND CULTURAL TRAUMAS IN E. M. FORSTER'S A PASSAGE TO INDIA
}

\author{
Dr. Rashed Ahmad Daghamin, University of Hail, Saudi Arabia
}

\begin{abstract}
A Passage to India is a seminal source, which has a clinical approach at the colonial outrages, racial traumas, and the multifarious ramifications of racism that the Anglo Indians perpetrated on the locals. The novel socially and psychologically explores the unhealthy dimensions of the colonizer-colonized relationships. The disgusting attitudes of the English expatriates as well as the hatred of the Indians, is the primary foundation of the racial tension between the two races. The antagonistic relationships between the two extreme communities made the social life in India unbearable and miserable. The miserable situation in colonized India deteriorated due to the violations of the values and rights of the indigenous Indians. In A Passage to India, the average Indian individual seems to consider mistrust and suspicion as his/ her best guide. However, Indian citizens are exploited by the colonizer's rude demeanors and racial, condescending and frustrating attitudes which eat into the vitals of the Indian community, In A Passage to India, E. M. Forster, highlights these biased and prejudiced racial attitudes. E.M. Forster in the novel clinically excoriates the patronizing British ruling caste. He also condemns the intolerance of the Indian community represented by Dr. Aziz, who is guided by his intuitions, imagination and emotions rather than his sense of intellect and reasoning. This racial tension in the colonized Indian society can be condensed by adopting a sensible attitude based on adopting human values, such as interracial love, peace, harmony and understanding. This paper delineates how racism and its different multiple manifestations have an effect on the relationships between the characters of different races. Forster furthermore underscores various human values such as interracial tolerance, love and understating. The violations of these values, however, is considered as the root cause of the racial tensions in the British Raj. Forster channels his biting satire and harsh criticism against the British rulers due to their unbearable racist discriminations against indigenous natives. This study, therefore, critically highlights race relations and the traumatic effects of the British colonization.
\end{abstract}

Keywords: racism, India, forster, British raj, race, intolerance, racial tension. 


\section{Introduction}

Contemporary critical theories such as post-colonial theory have tried to explain attitudes that have shown biases and divisive tendencies on people. Race is one of the most important parameters of postcolonial theory that can provide an effective tool to examine fiction, and therefore human behavior and tendency. Racism is one of the biggest obstacles, which can obstruct any possible interracial affair between the colonizer and colonized; between the dominating and the dominated. Literature should be the weapon to fight against institutionalized racism and segregation. It is a wellknown fact that race, racism and oppression are one of the major issues, which postcolonial Literature sheds light on.

Post-colonial theory is meant primarily to highlight the concept of racism, in all its ramifications, marginalization and segregation perpetrated on the subalterns or "the others". Racism and oppression inflicted on the indigenous Indians have many harmful effects that included severe poverty, racial discrimination, hunger assault, physical and sexual assault, rejection and ejection, disharmony, social insecurity and dehumanization. Racism and oppression affect the mentality and the mode of living of the Indians, reducing them into the level of beasts; to a level of inferiority in every aspect of their lives. However, it is worth mentioning that the decentralized and oppressed Indian people have responded to the brutal English segregation by many ways, such as radicalism, intellectualism, peace and violence.

The post-colonial theory studies the impact of colonization on cultures, nations and societies. The theory shows how European, "the white" nations conquered and controlled "Third World" cultures and societies, and how these subaltern groups have responded to and resisted such infringements. Postcolonialism, therefore, shows an awareness of the social and cultural inferiority enforced by being in a colonized state. The novel, A Passage to India highlights the Political and cultural difficulties that de-colonized nations face.

Racism in literary studies is defined as the belief in the fact that genetic elements, which constitute race, are the primary determinants of human traits and capacities, and such racial differences produce an inherent superiority of a particular race over the other.
The concept of racism is derived from the word 'race' and it is believed that one racial or ethnic group is inferior to another and the unequal treatment is thus justified. Stokely Carmichael and Charles V. Hamilton point out their views regarding racism:

What is racism? The word has represented daily reality to millions of black people for centuries... [It consists of] the prediction of decisions and policies on considerations of race for the purpose of subordinating a racial group and maintaining control over that group...Racism is both overt and covert...We call these individual racism and institutional racism. The first consists of overt acts by individuals, which cause death, injury or violent destruction of property...The second type originates in the operation of established and respected forces in society, and thus receives far less public condemnation than the first type (2).

On the other hand, oppression is defined by the encyclopedia as torture or degrading treatment of the oppressed, and the use of threat or violence by the oppressor against the oppressed. The exercise of power and authority in a cruel and unjust manner is another aspect of oppression.

\section{A Passage to India: Historical Context}

A Passage to India (1924) by E.M. Forster was selected as one of the 100 great works ever written in English Literature by the Modern Library, and won the James Tait Black Memorial Prize for fiction. In this novel, Forster seems to perceive the English Empire from a critical point of view rather than a nostalgic one (Enos 88). The theme of the book is the non-superficial relationship of the indigenous local Indians and the colonialist English. The novel is an attempt at understanding India and the natives from a more personal, positive and meaningful perspective (Enos 105). However, as Boehmer points out "it holds out little hope either for social interaction between Europeans and Indians, or for Indian national independence" (101).

The political significance of interracial relationships in the socio-historical context of A Passage to India, that is, colonial British India before the passing of the declaration of independence in 1947, was obviously remarkable. E. M. Forster paid two visits to the British colonial India, the first journey was in 1912 and the second one was in 1921. In A Passage to India, Forster worked in his own experiences and attitudes, which he 
experienced in India. The novel is widely considered as a "telling attack on British imperialism" (Botheroyd 6), and it is about relationships, mysticism as well as politics. $A$ Passage to India is written in the tradition of the former novels which deal with relationships and love; however, the political part in it, Forster's harsh criticism and biting satire against the British rule in the subcontinent of India, is based more on his ethical convictions than on political ones. Friendship for him is very important, perhaps even more important than love (Botheroyd 3).

Forster experienced a multifaceted India, which seemed strange to him, the phrase "a hundred Indias" is used several times to describe the muddle and mystery of the country. Forster is "appalled by the corruption of personal relationships produced by imperial rule". In India, there existed other divisions than in England. There were not only the class divisions that are produced by birth and wealth, but also a racial and religious division between people. There was a strong hierarchy in British India (Botheroyd 3).

E.M. Forster is an anti- colonial and anti-imperialist as his classic masterpiece, A Passage to India, exemplifies the condemnation of colonialism, racism and its multiple facets. In "A Passage to India and Heart of Darkness: A Comparative Study of Anti-Colonialism", both authors Md. Ishrat Ibne Ismail and Shareefa Yasmeen argue that "Forster's humanism fails to synthesize colonialism and post colonialism and leaves the matter undecided" (11). At the end of the novel, the friends Aziz and Fielding end their last meeting with a note of separation. In reply of Fielding's friendship Aziz, echoing Kipling's sayings 'the twin shall never meet,' says that East and West cannot be bridged.

The novel sheds light on the unhealthy dimensions of the relationships between the colonizers and the colonized. The Bridge Party is a perfect example demonstrating the colonized-colonizer unhealthy social relationship. The British are offering the bridge party to demonstrate the wide gulf between East and West, as Mrs. Turton says, "I refuse to shake hands with any of the men" (Forster 41).

In A Passage to India, it is realized that humanity of the native people is ignored, and the feelings of the colonized are disregarded. The locals are stripped of their humanity and dignity. It seems that the British colonizers have crossed the boundaries of humanity to the extent that they can be named uncivilized, e. g. telling lies about the natives, hurting them physically and psychologically, looking upon them as lower class and downtrodden. Above all, the colonizers disregard the values and passion of a human being. The IndoEuropean relationship is tested through the discourse of Dr. Aziz's attempt to assault an English lady, Miss Quested. Seizing this opportunity, the English rulers manipulate the event for their interests totally ignoring the urge of humanity (Ismail and Yasmeen 10). The English colonizers are always ready to seize advantage from a discourse:

Imperial relations may have been established initially by guns, guiles and diseases, but they were maintained in their interpellative phase largely by textuality, both institutionally...and informally. Colonialism, (like its counterpart racism), then, is a formation of discourse, and as an operation of discourse it inerpellates colonial subjects by incorporating them in a system of representation (Tiffin and Lawson, quoted in Loomba 95).

Hence, in A Passage to India, Adela is the victim who tests the elasticity of the Indo-British colonial relationship.

Both Ismail and Yasmeen argue that British's insatiability for geographical expansion and greed for wealth have corrupted the colonized society and has caused gross inhuman exploitation (8). At the core of the civilizing mission the intention is economic benefit as Ania Loomba argues, "[i]n whichever direction human beings and materials travelled, the profits always flowed into the so called mother country" (02). Jean-Paul Sartre, in his "Preface" to The Colonizer and the Colonized confesses the same notion emphasizing the economic aspects of colonization: "For me the economic aspects of colonialism is fundamental," and denunciates, "the so-called moral or cultural mission of colonization" which shows the profit motive as its basic. He further notes that "the deprivations of the colonized are almost direct result of the advantages secured to the colonizers" (qtd in Memmi XII).

\section{Discussion}

The English colonization of the subcontinent of India and its racial manifestations frustrates any potential friendship between the English and the Indians under the colonizer/colonized status quo. The novel 
underscores the process of 'formatting' and brainwashing which the English newcomers have to go through in order that they end up just like the other Anglo -Indian colonial settlers in terms of their ideologies and practices (Abu Baker 68). Clare Brandabur remarks that $A$ Passage to India "attempt[s] to deal with colonialism (or post-colonialism or neocolonialism) with respect to the destructive impact on personal relationships caused by the racist assumptions and psycho-pathology inherent in colonial imperialism" (Brandabur 19). Jan Mohamed argues that, the novel A Passage to India attempts "to overcome the barriers of racial difference'" (Childs 348). Nirad Chaudhuri, on the other hand, criticized it "for its reduction of political history to a liberal's preoccupation with personal relationships" (Childs 347).

Bhupal Singh conceives the novel as "a clever picture of Englishmen in India, a subtle portraiture of the Indian (especially the Moslem mind) and a fascinating study of the problems arising out of the contact of India with the West" (Singh 221). Besides, Meenakshi Mukherjee points out that "[p]erhaps relationship-communication between, and understanding of, men who happen to belong to two races-is part of Forster's theme" (Mukherjee 86). According to Nihal Singh, the novel depicts "how the British in India despise and ostracise Indians, while on their part the Indians mistrust and misjudge the British" (Childs 347). To Diane Johnson, one of the novel's themes is "that people from different cultures rarely understand one another" (Johnson 2000).

The novel focuses on the three characters: Dr. Aziz, his British friend Cyril Fielding, and Adela Quested. During an excursion to the Marabar Caves, Adela charges Dr. Aziz of attempting to rape her. Aziz's trial brings out all the racial tensions and prejudices between Indians and the British colonialists who rule over India.

Race, according to New Oxford Dictionary of English, is "Each of the major division of human kind, having distinct physical characteristic, a group of people sharing the same culture, history, language, etc (2003). According to Cambridge International Dictionary of English"race is group especially of people with particular similar physical characteristics, who are considered as belonging to the same type are the fact of belonging to a particular such group" (2000).
Gulzar Jalal Yousafzai and Qabil Khan in their research paper entitled "Rudeness, Race, Racism and Racialism in E.M. Forster's "A Passage to India" argue that attitudes of racialism, racism and race are viewed from various angles. They are discussed in the light of human psychology (86). A new dimension of A Passage to India has been discussed and analyzed by Rebecca Gronstedsin in her research article, "Racialism in A Passage to India". Accordingly, race is the classification of human beings into physically, biologically and genetically distinct groups. Race is further divided into racism and racialism. They stand for external and internal features. Racism is physical and a behavior, rcialism is theoretical and ideological, a doctrine, a principle. Rebecca says: "The ideology of racialism originated in Western Europe in the mid eighteen century and extended to about mid-twentieth, which suggest that Forster was influenced by its doctrines in the writing of his novel" (qtd in Yousafzai \& Khan 86).

Colonialism has often been considered as the struggle to determine who is fittest, even in the times before Darwin (Boehmer 80). According to Darwin, it was the Europeans who were the fittest of mankind. It was thanks to this quality that they were able to defend their colonies (Boehmer 85). Boehmer argues that "if colonization was a struggle for supremacy, not only of white against black, but between European nations, the scramble for territory took on the aspect of a conflict between competing virilities" (80).

Following 1857, the Indian Raj came into the clutches of the English rulers. The disgusting attitude of the English expatriates as well as the hatred of the Indians, is the primary foundation of the tension between the two races. The antagonistic relationships between the two extreme communities made the social life in India unbearable and miserable. The miserable situation in colonized India deteriorated due to the violations of the values and rights of the indigenous Indians. In A Passage to India, the average Indian individual seems to consider mistrust and suspicion as his/ her best guide. However, Indian citizens are exploited by the colonizer's rude and racial condescending attitudes.

In A Passage to India, E. M. Forster, highlights the biased and prejudiced racial attitudes of the English community, he also underscores various human values such as interracial tolerance, love and understating. The violations of these values, however, is considered as the 
root cause of the racial tensions in the British Raj. Forster channels his biting satire and harsh criticism against the British rulers due to their unbearable racist discriminations against indigenous natives (Khan \& Yousafzai 76).

In A Passage to India, the ruling Anglo-Indian colonialists are the stronger race and have therefore authority and dominance over the ruled, the separated, marginalized, segregated; the locals. This authority gives them supremacy and power which they use against the second class and inferior race, the Indians (Boehmer 10). The untouchable Indians are considered as weak, outcast, unwanted and second rate. They are believed to be different from Europeans, especially the English, compared with the white superiors; they are looked at as downtrodden and inferior. Even though the British might have their own different categories like social class and religions, they are united as opposed to the local natives (Boehmer 67). There is very little social integration between the colonialists and the Indians, between the racially superior and inferior. Yet there are incidents in the novel that show that the Indians are more sophisticated than the colonialists.

Forster had spent a long time in India before writing his book. On returning to England, he related to his friends that he had always felt miserable at the English Club, yet, on the other hand, in the company of Indians he always felt happy (Forster 11). Forster says: "looking back on that first visit of mine to India, I realize that mixed up with the pleasure and fun was much pain. The sense of racial tension, of incompatibility, never left me. It was not a tourist's outing, and the impression it left was deep (11).

Masood, an Indian friend of Forster, who lived in England writes in one of his letters:

When I began the book I thought of it as a little bridge of sympathy between East and West, but this conception has had to go; my sense of truth forbids anything so comfortable. I think that most Indians, like most English people, are shits, and I am not interested whether they sympathize with one another or not. Not interested as an artist; of course the journalistic side of me still gets roused over these questions... (qtd in Forster 15).

Ten years after publishing $A$ Passage to India, Forster confirmed the statement that a Victorian writer, William
Arnold, had made that "until the point of divergence between Eastern and Western mentality has been discovered, co-operation is impossible (Boehmer 150). The paper investigates the conflict of cultures that occur as a result of racism and misunderstandings between the colonial English rulers and the indigenous Indians. $A$ Passage to India is therefore an investigation whether there could be an invisible bond of value rather than an investigation of a political bond. The novel considers whether it is possible for personal relationships between the locals and English to develop to mutual satisfaction (Halmstad 6). Forster's novel reflects whether the English can connect with the Indians, and vice versa (Forster 26).

Throughout the novel there are examples of racist attitudes, persecution and oppression by the AngloIndians against the native Indians. The English doctor, Major Callendar brags about torturing an injured Indian youth by putting pepper on his shattered face. On the other hand, the police superintendent, Mr. Mc Bryde expresses supercilious views of the lust the Indians have for white English women. Ronny Heaslop, the city magistrate is ignorant, Miss Dereck shows rage towards her Indian employers; and MrTurton is arrogant towards the Indians (Halmstad 6).

Forster in the discussed novel says, "A community that bows the knee to a Viceroy and believes that the divinity that hedges a king can be transplanted, must feel some reverence for any viceregal substitute. At Chandraporethe Turtons were little gods" (25). He observes the overall attitude of the major Communities towards each other and finds them very biased, partial, disgusting, and prejudiced. "The roads, named after victorious generals and intersecting at right angles, were symbolic of the net Great Britain had thrown over India"(14). Similarly, "It was the anthem of Army of Occupation. It reminded every member of the Club that he or she was British" (23). His focus is the high ups, "The collector could not speak at first. His face was white, fanatical and rather beautiful - the expressions that all English faces were to wear at Chandrapore (152).

The observation and conclusion developed by McBryde, the English Police Officer, is also very queer, the District Superintendent of Police is never surprised by the behavior of any Indian and has his own theory about climatic zones. 
...no Indian ever surprised him, because he had a theory about climatic zones. The theory ran: All unfortunate natives are criminal at heart, for the simple reason that they live south of latitude 30. They are not to blame, they have not a dog's chance- we should be like them if we settled here (156).

McBryde, while opening his arguments truth, the darker races are attracted to the fairer but not vice versa" (206). In McBryde's opinion, Aziz behaves cruelly and brutally to an English female and cannot be forgiven. The policeman is quick to blame the Indians as all the colonialists did. "Quite possible, I'm afraid; when an Indian goes bad, he goes not only very bad, but very queer" (Forster 177).

The first attempt, to bridge the English and Indian communities, fails due to rude and racist attitude of the Anglo-Indian expatriates.

The Bridge Party was not a success - at least it was not what Mrs. Moore and Miss Quested were accustomed to consider a successful party. "They arrived early, since it was given in their honour, but most of the Indian guests had arrived even earlier, and even stood massed at the farther side of the tennis lawn, doing nothing (Forster35).

During the party, Mrs. Turton does not like to receive, mix up or be polite with the Indians. Mr. Turton reminds her, "To work, Mary, to work cried the collector touching his wife on the shoulder with a switch. Mrs. Turton got up awkwardly. What do you want me to do?" (Forster 37).

The observation of Adela is more than anyone else. She tells Fielding,

This party to-day makes me so angry and miserable. I think my countrymen out here must be mad. Fancy inviting guests and not treating them properly! ... The Englishmen had intended to play up better, but had been prevented from doing so by their women folk, whom they had to attend, provide with tea, advise about dogs, etc. When tennis began, the barrier grew impenetrable. It had been hoped to have some sets between East and West, but this was forgotten, and the courts were monopolized by the usual club couples (Forster 12).
The dialogue between Ronny and Mrs. Moore is also an example of a rude behavior:

We're not out here for the purpose of behaving pleasantly!

What do you mean?

What I say. We're out here to do justice and keep the peace.

Them's my sentiments. India isn't a drawing room. ents are those of a god," she said quietly, but it was his manner rather than his sentiments that annoyed her. Trying to recover his temper, he said, "India likes gods. And Englishmen like posing as gods (Forster 45).

The English and Indian communities strive to come closer to each other, however, they stand against each other because they bear some negative attitudes such as, racial discrimination, mutual hatred, disgust, rudeness and haughtiness. Such racial barriers, lack of mutual trust, and condescending attitudes act as main hurdles which could widen the racial gap between the two parties (Khan \& Yousafzai 77).

The existence of the racial tension between the two communities mounts up from the second chapter throughout the dialogue of the Indian Muslim characters. Dr. Aziz, a physician, Mahmoud Ali, an advocate, and other friends are discussing the demeanors of the members of the English ruling community, and how their attitudes towards Indians have changed after their coming to India (Khan \& Yousafzai 79). Dr. Aziz says that: "they all become exactly the same - not worse nor better. I give any Englishman two years, be the Turton or Burton. It is only the difference of a letter. And I give any Englishwoman six months. All are exactly alike" (Forster 9).

Throughout the novel, the English expatriates prove the belief that they are superior to the Indians, they have instilled a sense of inferiority complex into the minds of Indians. Forster delineates a picture of the anxious situation between colonial rulers and the Indians. The comments, behavior, and treatment which the Indians receive at the hands of the British characters, demonstrate the English sense of aggrandizement (Khan \& Yousafzai 80).

These patronizing and disgusting attitudes channeled towards the Indian community are due to historical, psychological, philosophical, cultural and traditional 
behavior. Indians are always humiliated in a way or another by the English ruling class. Dr. Aziz, for instance, is called upon urgently and unnecessarily by his superior Major Callendar, to his bungalow. This urgent and unnecessary call irritates and humiliates him, and thus embitters him. A highly qualified and educated Indian chap is unnecessarily asked to come at a bungalow, not at the hospital, and not for any official matter, an operation or emergency duty etc. Aziz feels it and discusses it with his Muslim friends. He complains, "Old Calendar wants to see me in his bungalow, he said. Some case, I dare say. I dare say not. I dare say nothing. He has found out our dinner hour that's all and chooses to interrupt us every time in order to show his power" Forster (13).

Racial tension between the communities is due to lack of tolerance, understanding, and prudence. Forster says, "on the basis of tolerance a civilized future is built. This is the only force which will enable different races and classes and interests to settle down together to the work of reconstruction" (qtd in Grandsen 5). The ruling British community deliberately put the Indians at a distance and does not tolerate them. This lack of tolerance aggravates the problem of reaction, harshness, retaliation, revenge, misunderstanding and hatred. Intolerance rises at the colonized Indian society due to attitudes of rudeness, race, racism and racialism. Henceforth, in spite of the great mutual affection between Dr. Aziz and Cyril Fielding, Aziz is eventually alienated from Fielding (Khan \& Yousafzai 89).

K .W. Grandsen argues that "Forster's literary career can more fruitfully be regarded as an attempt to explore and where this seemed to him desirable, to criticize and modify, the values and attitudes he had learnt as a young man"(5).

This grisly racial discrimination and gross injustices show the Anglo-Indians racial attitudes towards Dr. Aziz after the Marabar Caves' incident. MrMcBryde feels that Aziz pretends to be a reputable and respectable member in the Indian society, getting a government post, while in reality he is leading a double life. His negative way of life takes over his respectable self. Mr.Turton states that he has "never known anything but disaster result when English people and Indians attempt to be intimate socially" (Forster 182). According to Mr. Turton, contact and courtesy would be allowed, but intimacy should not be allowed for it is harmful. Only mutual respect and esteem can enable them to socialize with each other (Halmstad 7).

The British colonialists feel that it is necessary for them to abide by the unwritten rules on how they behave towards the local Indians. These unwritten rules, which the locals are bound to follow in their relations with the colonialists, safeguard the interests of the British, making them the white superiors. Any modification of these rules would risk the whole system (Boehem 68).

When Indians live in England, they can be extremely close to and respected by the English. However, the Indians cannot not return this hospitality when these Englishmen move to India. The Anglo-Indians would already have influenced these fellow Englishmen to put a stop to such friendships (Halmstad 7). When discussing this with Aziz, Hamidullah, an Indian lawyer, argues that: "It is impossible here. Aziz! The red-nosed boy has again insulted me in court. I do not blame him. He was told that he ought to insult me. Until lately he was quite a nice boy, but the others have got hold of him" (Forster 34).

Accordingly, as Hamidullah states, such a friendship between an Englishman and an Indian on an equal basis is only imaginable in England, "only contend that is possible in England" (Forster 33). Even Aziz feels, "Why talk about the English? Brrr....! Why be either friends with the fellows or not friends? Let us shut them out and be jolly. Queen Victoria and Mrs Bannister were the only exceptions, and they're dead" (Forster 33).

One must also consider the Englishmen who travel to India and have never had Indian friends in Briton. Many of them intend to be gentlemen and befriend Indians in the beginning; nonetheless, after a while they are told that this is not acceptable in English society. A dramatic change can be seen and some of these same Englishmen even begin to abuse the Indians (Halmstad 8). This can also be seen in the behavior of Mr.Turton: he too had been close to the locals originally and yet, like all the others before him, later on he did not trust any Indian. When Fielding first arrives in India he is extremely friendly, and wishes to be liked and accepted by the Indians. He chooses to befriend Indians. Yet even he, with his positive opinion of the Indians, feels at times that Indians are unbearable (Forster 184). 
The incident in the caves is a muddle or a mystery that shows that India can only present confusion of morals, misunderstandings and misreading between the colonialists and the locals (Childs 349). The personal relationships of Adela are given no importance; she is still the one who gives Fielding the chance to meet Aziz. Fielding and Adela are rejected by the English community due to their friendships with and loyalty towards the Indian community.

In "Rethinking Identity: The Coloniser in E. M. Forster's $A$ Passage to India", Ahmad M.S. Abu Baker argues that stereotypes presented in the novel are extremely strong, therefore, their lifecycle is long. Ronny tries to promote stereotypes and racial discourses to his mother, Mrs. Moore, using "phrases and arguments" of senior colonizers (76). He almost succeeds in making her adopt that same logic. "In the light of her son's comment she reconsidered the scene at the mosque .... Yes, it was all true, but how false a summary of the man; the essential life of him had been slain" (Forster 55). The discourse of the colony is strong, but Mrs. Moore's robust Christian belief, which has not been contaminated by colonization, makes her resist the imposition of this foreign discourse on her mind, although she acknowledges its "truth" (Abu Baker 76).

Colonization always conceals its true motives behind the mask of bringing knowledge and civilization to the colonized race. "It is here that the astonishing mental attitude called 'paternalistic' comes into play. A paternalist is someone who wants to stretch racism and inequality farther-once admitted" (Memmi, 74-76).

Ronny tries to convince both himself and Mrs. Moore of the British important presence in colonial India (Abu Baker 77). The English colonizers claim that they carry the white man's burden, and they have the mission of "bringing light to the colonizer's ignominious darkness" (Memmi 74-76). This "mission" legitimizes the colonization and enslavement of other races. Edward Said also notes the depiction of colonized races as being "naturally subservient to a superior, advanced, developed, and morally mature Europe" (Eagleton et al. 72). Thus, Ronny proclaims that " $[w] e^{\prime}$ 're out here to do justice and keep the peace. Them's my sentiments." Mrs. Moore, however, can see through his words. She protests:
'Your sentiments are those of a god,' ... Trying to recover his temper, he said, 'India likes gods.' 'And Englishmen like posing as gods' [Mrs Moore] '...and the country's got to put up with us, gods or no gods ...' .... We're not pleasant in India and don't intend to be pleasant. We've something more important to do' (69).

The interracial tension between the Indian and English communities is due to wrong attitudes of intolerance, hatred, and ill-treatment that the English man practiced against the local Indians. Forster believes that a civilized future is built on the basis of tolerance. Tolerance, peace, mutual understating, and interracial love help opposing races come close together and settle down. The colonizer deliberately estranges and excludes the Indians. Such intolerance aggravates the problem of severity, retaliation, and misunderstanding. In spite of the reciprocated affection and understanding between Dr. Aziz and Fielding, friendship fails and it is eventually alienated. The novel symbolizes the view that the peaceful union and perfect understanding between East and West is impossible.

\section{Conclusion}

A Passage to India is a novel that defies the hypothesis that friendship can be maintained between the English and the Indians in a colonizer/colonized status quo. Fielding's excoriating criticism and biting satire of the British colonizers, of their racism and of the fear they base their regime upon is clearly evident in the novel. Based on inequality, bigotry, cruelty, and racism, colonization frustrates any attempts towards having a friendship between the Indian locals and the British ruling colonizers, between Aziz and Fielding.

The paper concludes that friendship between the two opposing forces fails as there are many drawbacks between the two different and opposing races. The British colonizers develop a rude political attitude as they issue wrong and partial prejudgments about the indigenous Indians. This inferior treatment on the English part damages any potential efforts of forming friendship between both conflicting races. The Indians, therefore, lose any glimmer of hope of making any advancement in this regard, and they as a result of this inferior treatment get more embittered and desperate; they quit attempting to approach the colonizers. Friendship between the Indians and the British seems impossible while India is under British occupation, and as Forster suggests in the last chapter of the book, it is 
only possible after the departure of the British colonizers. Friendship can only be made between the two different sides when they are equals in theory and practice. 


\section{References}

Abu Baker, A. M.S. (2006) "Rethinking Identity: The Colonizer in E. M. Forster's A Passage to \India". Nebul 3.23, 68-85. Print.

Ashcroft, B., Gareth, G. \& Helen, T., eds. (1995) The post-colonial studies reader. London: Routledge.

Boehmer, Elleke. (1995) Colonial and Postcolonial Literature: Migrant Metaphors. Oxford: Oxford UP.

Botheroyd, Dr. "The influence of British imperialism and racism on relationships to Indians in $E$. M. Forster's " $A$ Passage to India" and how this topic is presented in the film by David Lean" Sabine RiesSkandinavistik, Film- und Fernsehwis senschaft,Anglistik(LeistungnachweisinAnglistik), retrieved 1 September 2018 from https://www.audimax.de/fileadmin/hausarbeiten/anglistik/Hausarbeit_Anglistik_Introduction_to_Com monwealth_studies through_film.pdf. Web. 2001.

Brandabur, C. (1993) "Images of women in five post-colonial novels", Aegean Journal of Language and Literature, proceedings of 13th All-Turkey English Literature Conference 1992 (special issue), Izmir.

Carmichael, S. \& Hamilton, C. V. (1967) Black Power: The Politics of Liberation in America. New York: Vintage Books.

Childs, P. ed. (1999) Post-colonial theory and English Literature; A Reader. Edinburgh: Edinburgh UP.

Eagleton, T., Fredric J. \& Edward S. (1990). Nationalism, Colonialism, and Literature. Intro. Seamus Deane. Minneapolis: University of Minnesota Press.

Enos, M. R. "Female Bodies, Native Tales: The Disciplinary Process in A Passage to India." (1996). Multiculturalism and Representation: Selected Essays edited by John Rieder and Larry E. Smith, Honolulu, Hawaii: College of Languages, Linguistics, and Literature, University of Hawaii : East-West Center, pp. 88-110.

Forster, E.M. (1979). A Passage to India. London: Penguin Books Ltd.

Granesden. K.W. (1962). E.M. Forster. Edinburgh and London: Oliver and Boyd.

Gronstedt, R., "Racialism in A Passage to India" (The Imperial Archive) retrieved 19 September 2018 from http://www.qub.ac.uk/schools/SchoolofEnglish/imperial/india/Racialism-\%20Forster.html, para. 23 of 28.

Halmstad, H. (n.d.). "The Colonialists versus the locals: Friendship in E. M. Forster, A Passage to India retrieved 25 September 2018 from https://pdfs.semanticscholar.org.

Ibne I., Md. Ishrat \& Shareefa Y. (2014) "A Passage to India and Heart of Darkness: A Comparative Study ofAntiColonialism." SUST Journal of Social Sciences 22.2, 8-1. Print.

Johnson, D. (2000). "Pesky Themes Will Emerge When You're Not Looking", Writers onWriting, New York Times, New York, Sept. 11, 2000.

Loomba, A. (1998). Colonialsim/Postcolonialsim. London: Rutledge.

Memmi, A. (1967). The Colonizer and the Colonized. Boston: Beacon Press.

Mukherjee, M. (1971). The Twice Born Fiction - Indian Novels in English. NewDelhi: Heinemann Educational Books Ltd.

New Oxford Dictionary of English Second Edition (2003).

Satin, N. (1976). India in Modern English Fiction. Norwood Editions.

Singh, M. A. Bhupal (1974). A Survey of Anglo-Indian Fiction. London: Curzan Press Ltd.

Yousafzai, G. \& Khan, Q. (2008)."Rudeness, Race, Racism and Racialism in E.M. Forster's "A Passage to India."The Dialogue IV. I., pp. 75- 92. Print. 
Rashed Ahmad Daghamin 